\title{
The complex dynamics of agriculture as a financial asset: introduction to symposium
}

\section{Edited by Jennifer Clapp, S. Ryan Isakson and Oane Visser}

This is the author version of the article published by Springer which appeared as (please cite the original):

- Clapp, Jennifer., S. Ryan Isakson, and Oane Visser (2016) 'The complex dynamics of agriculture as a financial asset: introduction to a symposium', Agriculture and Human Values, early view Doi: 10.1007/s10460-016-9682-7 NB: Page numbers correspond exactly with the original

\section{Author contact information}

Jennifer Clapp (jclapp@uwaterloo.ca) (corresponding author)

Environment and Resource Studies, University of Waterloo, 200 University Avenue West, Waterloo, ON, N2L 3G1, Canada

S. Ryan Isakson (ryan.isakson@utoronto.ca)

Centre for Critical Development Studies and Department of Geography, University of Toronto, 1265 Military Trail, Toronto, ON, M1C 1A4, Canada

Oane Visser (visser@iss.nl)

International Institute of Social Studies (ISS), Erasmus University Rotterdam, Kortenaerkade 12, The Hague, 2518 AX, The Netherlands 


\title{
The complex dynamics of agriculture as a financial asset: Introduction to symposium
}

\author{
Jennifer Clapp, S. Ryan Isakson and Oane Visser
}

\begin{abstract}
The contemporary process of financialization has been a major driver of the remarkable changes witnessed in global food and agricultural markets over the past decade, contributing to the rise and subsequent volatility of food and agricultural commodity prices since 2006. In the wake of these developments it has become clear that the turmoil has intensified the relationship between agriculture and finance in ways that have profound and enduring implications for the sector, and the people whose lives and livelihoods depend upon it. This symposium brings together four original research articles that contemplate the contemporary relationship between the agrifood and financial sectors. They examine a variety of overlapping themes, including the creation of financial assets from farmland and agricultural commodities, the activities of different types of investors in these assets in specific geographic contexts, and the challenges of governing this activity at the global scale. These articles show that the period of market volatility that began a decade ago reinvigorated investor interest in financial products linked to agriculture and farming, and inspired the packaging of new farms of financial assets in ways that have affected politics and practice on the ground, and are likely to leave a lasting legacy.
\end{abstract}

Keywords: Finance $・$ Investment $•$ Agriculture $・$ Food $\bullet$ Land

The contemporary process of financialization has been a major driver of the remarkable changes witnessed in global food and agricultural markets over the past decade. While other factors were certainly at play, financial speculation contributed to the rise and subsequent volatility of food and agricultural commodity prices in 2006, resulting in market turmoil affecting those who rely on those markets for their food and livelihoods (Clapp 2009; Ghosh et al. 2012; Heltberg et al. 2013; Lagi et al. 2012). Agriculture and food commodity prices have since stabilized, but in the wake of these developments it has become clear that the turmoil has intensified the relationship between agriculture and finance in ways that have profound and enduring implications for the sector, and the people whose lives and livelihoods depend upon it.

This symposium brings together four original research articles that contemplate the contemporary relationship between the agrifood and financial sectors. They examine a variety of overlapping themes, including the creation of financial assets from farmland and agricultural commodities, the activities of different types of investors in these assets in specific geographic contexts, and the challenges of governing this activity at the global scale. Even as agricultural commodity prices have eased on global markets in recent years, what these articles show is that the period of market 
volatility that began a decade ago re-invigorated investor interest in financial products linked to agriculture and farming, and inspired the packaging of new forms of financial assets in ways that have affected politics and practice on the ground, and are likely to leave an lasting legacy. Four interrelated themes stand out from these articles.

First, increased financial activity in the food and agricultural sector has resulted in a blurring of boundaries on a number of fronts. It has become increasingly difficult, for instance, to differentiate between the agricultural and financial sector, and between the different actors involved in financial investment in agriculture (Isakson 2014). In her contribution to this symposium, Clapp shows that banks and other traditional financial institutions, as well as pension funds and hedge funds, are increasingly engaging in commodity and farmland investments. Similarly, more conventional agrifood actors, such as commodity trading firms, are acting like financial firms. For example, Cargill, the world's largest grain trading company, is in a unique position between the financial and agricultural sectors. As Salerno discusses in her contribution to the symposium, the firm has recently expanded its activities into the financial realm through the creation of a number of financial subsidiary companies that actively invest in the agricultural sector. In addition to its long-standing practice of hedging its own financial risks in derivatives markets, Cargill now sells commodity-based financial products to third parties. Meanwhile, it has intensified private equity investments in suppliers that not only help to ensure the trader's access to physical commodities, but also generate valuable data that informs Cargill's activities in derivatives markets and generates further profits on equity sales. Combined, Clapp and Salerno's articles shed light on a complex matrix of investments between the agrifood and financial sectors and a blurring of boundaries between them.

In addition to the greying between financial and 'real' activities, the blurring is evident along at least two other dimensions. One is the difficulty of distinguishing between bona fide hedging and pure financial speculation in agricultural commodity markets. Commodity trading firms insist that any financial activity on their own account is simply hedging, but determining whether that is the case, as Salerno and others have pointed out, is difficult in practice (Clapp 2015; Murphy et al. 2012). There is also a blurred understanding of farmland 'productivity'. With the recent growth of financial assets based on agriculture and farmland, it is increasingly unclear whether productivity refers to agricultural production, the returns on the financial asset, or both. This tension is highlighted in the contributions to this symposium by Visser and Ducastel and Anseeuw (c.f. Fairbairn 2014; Visser 2015). Visser, for instance, describes how the agricultural holdings in Russia (and Ukraine) initially focused on land appreciation but, upon the realization of stagnating capital gains, gave greater attention to agricultural production.

A second key theme that emerges from the papers is the wide diversity of actors engaged in the process of turning farmland and agricultural and food commodities into financial assets. The papers identify a broad range of actors, including investment banks, real estate firms, farm management enterprises, large agricultural companies (a broad and diverse category in and of itself), commodity trading firms, hedge funds, and pension fund managers. The wide diversity of actors engaging in these activities, combined with the varying nature of their financial activities, has contributed to confusion and has made researching this issue particularly challenging. The principal actors involved might be different in each case, making it virtually impossible to generalize about the process of financial asset-making in the sector. The articles in this symposium illustrate this point, as they feature different actors taking on diverse roles in different contexts. Ducastel and Anseeuw's analysis features the role of brokers in converting South African farmland into a financial asset class, where, fund managers have a central role. Whereas as Visser's analysis shows, in Russia large agricultural holdings, sometimes assisted by real estate consultants, are the central actors. For their part, Salerno and Clapp highlight the complex range of actors involved in the commodification and financialization of agricultural commodities, and the extent to which their activities overlap. As Clapp points out, pension funds, for example, may be investing in hedge funds, which in turn may be subsidiaries of large commodity trading firms. Salerno's analysis features the commodity trading firm Cargill as a key actor in this chain of participants in the sector.

Third, the ways in which financial assets associated with farmland, food and agricultural commodities have emerged and operate are highly complex. The articulation of different assets in the food and farmland sector into the financial sector is unique in each of the cases examined. However, as several of the articles in this symposium show, there are a number of general conditions that must hold and steps involved in turning farmland, for example, into a financial asset for investors. Ducastel and Anseeuw show through the case of two farmland funds in South Africa, that a predictable flow of revenue, a standardized information flow, and a distancing from the social context are all important features of transforming farmland into a financial asset for investors. Similarly, Visser looks at the process of turning farmland into a financial asset in Russia, and develops a typology for the different conditions that must apply for this process to be successful. These include profit potential, discursive scarcity, standardization, 
liquidity, and legitimacy. As Visser notes, however, the process is not always straightforward, and as the case of Russia shows, the promise of profitability to investors does not always mean that the farms involved are actually profitable on the ground. Meanwhile, as Salerno's article illustrates, the assemblage of financial assets is relatively less work for a powerful actor like Cargill, thanks in part to the dominant role that it plays in a number of agrifood supply chains.

Fourth, the blurring of sectoral boundaries, the diversity of actors, and the complexity of financial instruments have all contributed to difficulties in crafting effective governance mechanisms to address potential externalities arising from increased financial investment in the food and farming sector. Clapp shows, for example, that the political challenges of regulating activity in this area has resulted in voluntary rather than mandatory approaches to governing financial investment in the sector. The rise of voluntary financial responsibility, however, suffers from a number of weaknesses that have already been identified with respect to voluntary initiatives more generally. These include weak enforcement capacity, low participation rates, a weak business case for sustainability measures, and a confusing array of initiatives that can vary significantly in their requirements and effectiveness. The diversity of investors and complexity of financial instruments involved complicate efforts to discern which actors should bear the burden of responsibility, and how to ensure that they do so. The end result, Clapp argues, is that the voluntary responsible investment initiatives for agriculture are more likely to shape discourse than practice. Yet at the same time, as Salerno observes, the increasingly fuzzy distinction between the speculative and hedging practices of major grain traders like Cargill, combined with their lobbying efforts, create challenges for traditional regulatory prescriptions like position limits in commodity derivatives markets (c.f. Murphy et al. 2012; Helleiner 2015).Combined, Clapp and Salerno's articles raise the questions of whether and how finance can be harnessed to advance a sustainable, effective, and socially just food economy.

Together, the articles in this symposium show that profound changes have occurred as a result of the intensified interest in agriculture and farmland as a financial asset over the past decade. These changes have occurred on several levels. At the level of farming and farmland, there has been a change in landholding practices. As both Visser and Ducastel and Anseeuw illustrate, the process of turning agricultural land into a financial asset requires a depoliticization of land control. Yet, by its very nature, control over land is an inherently political question (e.g. Borras 2007; Li 2015), meaning that such abstraction can contribute to the silencing of certain claims. Changes are also occurring in actual farming practices. In order to realize returns from agricultural production, finance pushes for the increased capitalization of agricultural production, particularly the mechanized production of row crops (HighQuest 2010). Yet these changes have profound implications for social relations of agricultural production as well as for the natural environment. While it need not be the case, such capitalization of agriculture is often associated with the displacement of agricultural labor while those who continue to work the land do so as poorly compensated and insecure wage laborers (Akram-Lodhi 2013; Binswager 1986; Deere and León 1981). Meanwhile, the short-term improvements in yield that are associated with mono-cropping and the increased use of commercial inputs are often linked with declining soil fertility, soil and groundwater contamination, reduced biodiversity, and, ultimately, less resilient food systems (Altieri 1995; Holt-Giménez 2002; Perfecto et al. 2009).

There has also been a discernable change in strategy among different actors, as all of the papers in this symposium show. For example, increased financialization in the sector has resulted in an increased ability for commodity trading firms to hedge their financial risks with more complex financial instruments. At the same time, banks become more involved in trading physical commodities as a hedge against the agricultural-linked products that they are increasingly offering to investors. And investors now have more avenues to diversify their asset mix into agricultural and farmland investments. Large institutional investors can invest in agriculture through farmland funds of private equity firms and hedge firms (Daniel 2012; Ducastel and Anseeuw this issue), through Real Estate Investment Trusts (REITs) (Fairbairn 2014; Gunnoe 2014), or by buying shares directly in large stock listed agricultural companies, which have emerged in Latin-America (Fairbairn 2014), Russia and Ukraine (Visser, this issue), and Australia (Magnan 2015).

Governance approaches are also affected by these developments. Voluntary measures tend to dominate despite the well-known weaknesses with this approach. Meanwhile, traditional approaches to regulate speculative activity in agricultural derivatives markets have been complicated by corporate concentration along agrifood supply chains (Murphy 2008; Clapp 2012). Vertical integration by major commodity traders, combined with their increasing forays into financial markets, have further blurred the already grey distinction between speculation and hedging (Salerno, this issue; Clapp 2015). At the same time, innovations in finance have lengthened agrifood supply chains and introduced new challenges in identifying the role played by specific investors (Clapp 2014). The implication is that traditional means for regulating financial activities, like position limits, 
are complicated as are more recent attempts like voluntary guidelines for socially responsible investing (Helleiner 2015).

These new conditions, which have emerged as a result of increased financial activity in the farmland and agricultural commodity sectors, are likely to persist, even in the wake of a decline of speculative interest in food and farmland. The recent financialization of the sector has altered the norms, practices, and institutional settings in important ways. As these new forms of asset-making and financial practices become more prevalent and normalized without strict regulatory controls in place to safeguard against the associated social and environmental costs, the stage is arguably set for a future rally of financial actors in this sector. These conditions suggest that the time to address these issues is now, rather than waiting for the next crisis to strike in the sector.

\section{Acknowledgements}

We would like to thank Rachel McQuail for editorial assistance in preparing this symposium. The article benefitted from support from European Research Council (ERC) grant 313871, the Social Sciences and Humanities Research Council of Canada, and the Trudeau Foundation.

\section{References}

Akram-Lodhi, A.H. 2013. Hungry for change: Farmers, food justice and the agrarian question. Black Point, Nova Scotia: Fernwood.

Altieri, M. 1995. Agroecology: The science of sustainable agriculture ( $2^{\text {nd }}$ Edition). Boulder: Westview. Binswager, H. 1986. Agricultural mechanization: A comparative perspective. World Bank Research Observer 1(1): 27-56.

Borras, S.M. 2007. Pro-poor land reform: A critique. The University of Ottawa Press: Ottawa.

Clapp, J. 2009. Food price volatility and vulnerability in the Global South: Considering the global economic context. Third World Quarterly 30(6): 1183-1196.

Clapp, J. 2012. Food. Malden, MA: Polity Press.

Clapp, J. 2014. Financialization, distance, and global food politics. The Journal of Peasant Studies 41(6): 797-814.

Clapp, J. 2015. ABCD and beyond: From grain merchants to agricultural value chain managers. Canadian Food Studies 2(2): 126-135.

Daniel, S. 2012. Situating private equity in the land grab debate. The Journal of Peasant Studies 39(3-4): 703-729.

Deere, C.D., and M. León. 1981. Peasant production, proletarianization, and the sexual division of labor in the Andes. Signs 7(2): 338-360.

Fairbairn, M. 2014. 'Like gold with yield': Evolving intersections between farmland and finance. The Journal of Peasant Studies 41(5): 777-795.

Ghosh, J., J. Heintz, and R. Pollin. 2012. Speculation on commodities futures markets and destabilization of global food prices: Exploring the connections. International Journal of Health Sciences 42(3): 465-483.

Gunnoe, A. 2014. The political economy of institutional landownership: Neorentier society and financialization of land. Rural Sociology 79(4): 478-504.

Helleiner, E. 2015. Positioning for stronger limits? The politics of regulating commodity derivatives markets. Paper presented at workshop The Politics of Regulating Global Derivatives Markets After the 2008 Crisis, Balsillie School of International Affairs, Waterloo Ontario, 19 September 2015. 
Heltberg, R., N. Hossain, A. Reva, and C. Turk. 2013. Coping and resilience during the food, fuel, and financial crisis. The Journal of Development Studies 49(5), 705-718.

HighQuest Partners, United States. 2010. Private financial sector investment in farmland and agricultural infrastructure. OECD Food, Agriculture, and Fisheries Papers, No. 33: OECD Publishing.

Holt-Giménez, E. 2002. Measuring farmers’ agroecological resistance after Hurricane Mitch in Nicaragua: A case study in participatory, sustainable land management impact monitoring. Agriculture, Ecosystems, and Environment 93(1-3): 87-105.

Isakson, S.R. 2014. Food and finance: The financial transformation of agro-food supply chains. The Journal of Peasant Studies 41(2): 1-27.

Lagi, M., Y. Bar-Yam, K.Z. Bertrand, and Y. Bar-Yam. 2012. Economics of food prices and crises. Cambridge, MA: New England Complex Systems Institute.

Li, T. 2015. Transnational farmland investment: A risky business. Journal of Agrarian Change 15(4): 560-568.

Magnan, A. 2015. The financialization of agri-food in Canada and Australia. Corporate farmland and farm ownership in the grains and oil seed sector. Journal of Rural Studies 41: 1-12.

Murphy, S. 2008. Globalization and the corporate concentration in the food and agriculture sector. Development 51(4): 527-533.

Murphy, S., D. Burch, and J. Clapp. 2012. Cereal secrets: The world's largest grain traders and global agriculture. [ebook] Oxford: Oxfam GB for Oxfam International. http://www.oxfam.org/sites/www.oxfam.org/files/rr-cerealsecrets-grain-traders-agriculture-30082012-en.pdf. Accessed 20 October 2015.

Perfecto, I., J. Vandermeer, and A. Wright. 2009. Nature's matrix: Linking agriculture, conservation and food sovereignty. London: Routledge.

Visser, O. 2015. Finance and the global land rush: Understanding the growing role of investment funds in land deals and large-scale farming. Canadian Food Studies 2(2): 278-286.

\section{Author Biographies}

Jennifer Clapp is a Canada Research Chair in Global Food Security and Sustainability and Professor in the Environment and Resource Studies Department at the University of Waterloo. Her most recent books include Hunger in the Balance: The New Politics of International Food Aid (Cornell University Press, 2012), Food (Polity, 2012), The Global Food Crisis: Governance Challenges and Opportunities (co-edited with Marc Cohen, WLU Press, 2009), and Corporate Power in Global Agrifood Governance (co-edited with Doris Fuchs, MIT Press, 2009).

S. Ryan Isakson is an Assistant Professor of International Development Studies and Geography at the University of Toronto. Broadly, he is interested in the political economy of food and agrarian change, particularly in the Latin American context. His current research projects explore how financialization and the development of flex crops contour land rights, rural livelihoods and the vulnerability of small-scale farmers in rural Guatemala. He is a coeditor of Global Agrarian Transformations, Vol. 1: New Directions in Agrarian Political Economy (Routledge, 2015).

Oane Visser is Associate Professor at the International Institute of Social Studies (ISS) of Erasmus University Rotterdam. His research examines farmland investment, financialization, rural social movements, and food security and food sovereignty in international perspective and regionally (Russia, Ukraine, Romania). He is principal investigator of a five-year European Research Council project on land investment (Grant 313781), coordinator of the Eurasian Agrofood and Land Initiative (EURAL), and an editor of Focaal- Journal of Global and Historical Anthropology. 